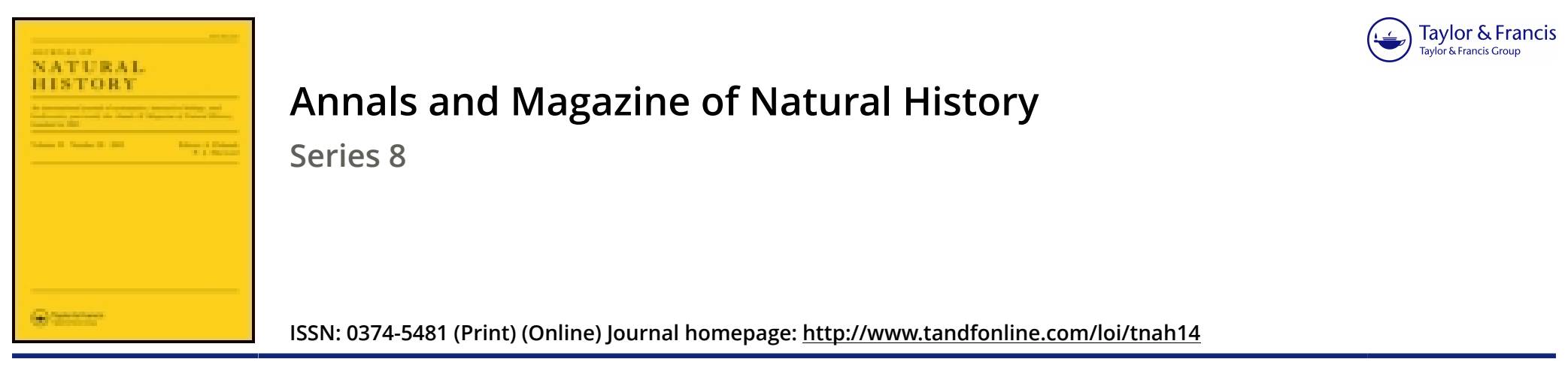

\title{
XLII.-Description of a new species and a new subspecies of European bats
}

\section{G.E.H. Barrett-Hamilton}

To cite this article: G.E.H. Barrett-Hamilton (1910) XLII.-Description of a new species and a new subspecies of European bats , Annals and Magazine of Natural History, 5:27, 291-293, DOI: $10.1080 / 00222931008692770$

To link to this article: http://dx.doi.org/10.1080/00222931008692770

册 Published online: 08 Sep 2009.

Submit your article to this journal $\sqsubset \pi$

Џlll Article views: 1

Q View related articles $₫$ 
and, further, the flagellated chambers and collar cells resemble those of Tetraxonid Sponges. Prof. Minchin has reminded me of the tendency of gemmule cells to accumulate at the base of a sponge, and has suggested that possibly the calcareous structure may be of the nature of a protective coating for gemmule cells. There are considerable difficulties, however, in the way of accepting this ingenious theory.

All that it was intended to bring out in these notes was the fact that Merlia is a sponge with a siliceous and calcareous skeleton, and that we are justified in assuming that there is now more evidence-slight as it still is-in favour of the theory that some Monticuliporas are Sponges than in that of any other theory as to the nature of these fossils.

A full account of Merlia with figures will shortly be published in the 'Quarterly Journal of Microscopical Science.'

\section{XLIT.-Description of a new Species and a new Subspecies of European Bats. By G. E. H. BakreTT-HaMilTon.}

There is in the British Museum of Natural History a bat taken in Roumania by the late $W$. Dodson, and having the general appearance of a small Serotine. I have long suspected this to be the first known example of a hitherto undetected species, but dared not describe it on the strength of a single specimen. Recently, however, Mr. Gerrit S. Miller, Jun., has had the courtesy to send me for comparison a similar although somewhat larger specinen from the collection of the United States National Museum, taken at St. Gothard, Switzerland. I have now, therefore, no hesitation in describing the new species as follows:-

\section{Vespertilio sodalis, sp. n.}

This bat resembles $V$. serotinus of Europe in general appearance, proportions and colour, but is smaller. 'The teeth are relatively larger though not so broad, the length of the cheek-series being actually about as long as in V. serotinus. The skull is relarively stouter and shorter and the cranium rounder and more inflated than in V. serotinus.

In colour the two specimens are dissimilar. In both the ears and membranes are, as usual, dusky. In the Roumanian bat the upperside is near "Prout's brown," the hairs being tipped with tawny, especially on the lower back; the underside is near "isabella color." The Swiss bat is everywhere 
much lighter, the upperside being near "russet" *, with tawny hair-tips, and the underside unicoloured deep "buff." The face, ears, and wings are very sparsely baired.

The dimensions of the two specimens in millimetres (the Roumanian bat first) are as follows :-

Head and body $63 \dagger, 76 \ddagger$; tail $42 \dagger, 32 \ddagger$; ear $18 \dagger, 14+\ddagger$; tragus, $6,8 \ddagger$; thumb without claw $6+, 8 \ddagger$; fifth metacarpal $39+, 40+$; fourth metacarpal $40+, 41$; third metacarpal 41 , 43 ; forearm (extreme length) 46, 48; lower leg $19+, 19+$; hind foot (without claws) $8+,-$

Skull: greatest length 19, - ; basal length in middle line 14 , - ; palatal length in middle line 7,8 ; from posterior border of $m^{3}$ to anterior border of canine $6+, 7$; same in lower jaw -, 8 ; greatest breadth at zygoma $13.5,-$; posterior breadth $8 \cdot 5,9$; breadth between orbits 8,8 ; breadth at constriction $4+, 4$. Blanks in the dimensions indicate that the skulls are damaged.

The type is a male, no. 4. 4.6.1 of the British Museum collection, taken at Bustenari, Roumania, on the 24th April, 1899 , by W. Dodson, collecting for the late Lord Lilford. It was shot in a wood, where the collector obtained also some Serotines. The second specimen, also a male, is no. $\frac{12338}{37295}$ of the U.S. Nat. Museum collection, from St. Gothard, Switzerland.

The existence of a second and smaller bat of the Serotine type in Europe is of some interest in view of Mr. Miller's recent demonstration that Myotis oxygnathus of Monticelli is practically a small $M$. myosotis. It recalls also the relations of Nyctalus noctula and $N$. leisleri.

Rhinolophus ferrum-equinum insulanus, subsp. $\mathrm{n}$.

Dr. Andersen's acceptance of Cabrera's $R$. ferrum-equinum obscurus as a small subspecies makes the treatment of the British Greater Horseshoe Bat somewhat difficult. The latter is undoubtedly smaller than the typical continental form, but its dimensions come so close to those of $R . f$. $-e q$. obscurus that distinction of the two would be difficult even on the average. But even granted that they are apparently identical, these two colonies are geographically separated and represent independent assumption of similar dimensions, recalling to a

* Names of colours in inverted commas are from Ridgwry's 'Nomenclature of Colors,' 1886.

$\dagger$ Collector's measurements.

$\ddagger$ Measured in dry skin. 
certain extent the case of the Lesser Horseshoc, in which the existence of two small forms, one Mediterranean, the other British, is not disputed. It seems, then, incorrect and impossible to identify British Greater Horseshoes with Spanish obscurus, while, on the other hand, Andersen's exact arrangement of the members of this genus precludes their identification with the typical form.

I understand that some naturalists do not recognize the validity of $R$. f.eq. obscurus, and on that view the case for the subspecific distinction of the British Greater Horseshoe becomes even stronger, and I feel compelled to give it subspecific rank. It may be known as $R$. ferrum-equinum insulanus.

This bat resembles $R$. ferrum-equinum ferrum-equinum of Europe in every respect, but has smaller wings.

The skull-measurements about equal those of $R$. f.eq. ferrum-equinum.

The following are the average dimensions of a series:$\left.\begin{array}{c}\text { Approximate average } \\ \text { of eleven males ... }\end{array}\right\}$

Approximate average of five females ...
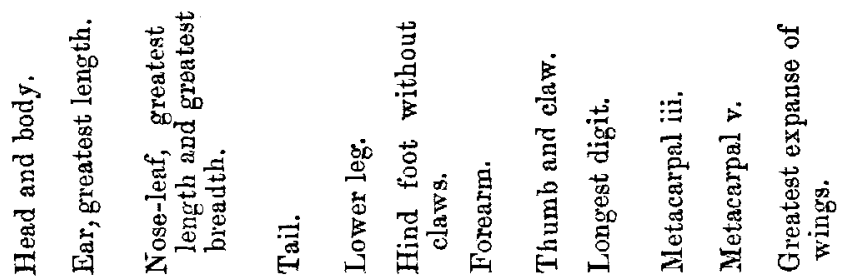

$63 \cdot 222$

$14.7 \times 8 \cdot 132$

The dimensions of the type are as follows (measured from alcohol) :-

Head and body $63 \mathrm{~mm}$.; ear, greatest length, 21.5 ; noseleaf, greatest length and breadth, $14 \times 7+$; tail 31 ; lower les 25 ; hind foot without claws 10.5 ; forearm 54 ; thumb and claw 6 ; longest digit 83.5 ; metacarpal iii. 36 ; metacarpal iv. 38 ; metacarpal v. 40.

Skull : greatest length 24 ; basal length in middle line 19 ; palatal length in middle line 8 ; from posterior border of $m \iota^{3}$ to anterior border of canine $8 \cdot 75$; ditto in lower jaw $9 \cdot 75$; greatest breadth at zygoma 12 ; posterior breadth 9 ; breadth between orbits 8 ; breadth at constriction 3 .

The type is no. 7. 1.10.3 of the British Museum collection, a male in alcohol. It was taken by Mr. 'I. A. Coward in the caves at Cheddar, Somersetshire, in January 1907. 